\title{
Influence of Integrated Nutrient Management Practices on Biomass Yield and Growth of Maize Crop in Acid Soil
}

\author{
Tupaki Lokya $^{1 *}$, Antaryami Mishra ${ }^{1}, J_{.}$Ravinder $^{2}$, Sugyata Shivhare $^{1}$ and Suraj Mali $^{1}$ \\ ${ }^{1}$ Department of Soil Science and Agricultural Chemistry, College of Agriculture, OUAT, \\ Bhubaneswar-751003, Odisha, India \\ ${ }^{2}$ Department of Soil Science and Agriculture Chemistry, UBKV, Pundibari, Cooch \\ Behar-736165, West Bengal, India \\ *Corresponding author
}

\begin{tabular}{|c|c|}
\hline \multicolumn{2}{|r|}{ A B S T R A C T } \\
\hline & \multirow{5}{*}{ 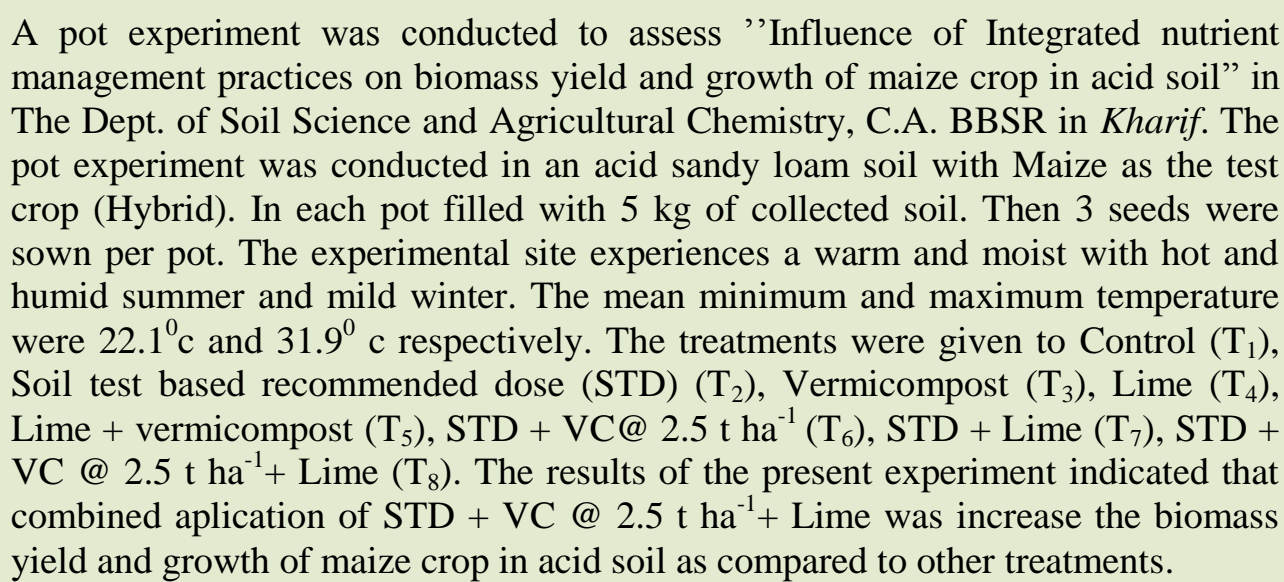 } \\
\hline & \\
\hline $\begin{array}{l}\text { Pot culture, Lime, } \\
\text { Acid soil, } \\
\text { Vermicompost, } \\
\text { Integrated nutrient } \\
\text { management. }\end{array}$ & \\
\hline Article Info & \\
\hline $\begin{array}{l}\text { Accepted: } \\
\text { 19 July } 2017 \\
\text { Available Online: } \\
\text { 10 September } 2017\end{array}$ & \\
\hline
\end{tabular}

\section{Introduction}

Soil acidity and elemental toxicities or deficiencies associated with it, affects crops growth and restricts yields throughout the world (Eswaran et al., 1997; Rengel et al., 2003). Acid soil with a $\mathrm{pH}$ lower than 5.50 are widespread in Croatia and cover a large area of arable land (Kovacevic et al., 1993; Loncaric et al., 2005). Amelioration of acid soil by different liming materials can raise soil $\mathrm{pH}$, benefiting soil properties and plant growth and liming is widely practiced for improving the acid soils productivity.
Soil acidity is a major yield limiting factor for crop production worldwide. Land area affected by acidity is estimated at 4 billion hectares, representing approximately $30 \%$ of the total ice-free land area of the world (Sumner and Noble, 2003). In the tropics, substantial weathering of soils over millennia has resulted in the leaching of crop nutrient bases (mainly $\mathrm{K}, \mathrm{Mg}$ and $\mathrm{Ca}$ ) followed by their replacement by $\mathrm{H}, \mathrm{Al}, \mathrm{Mn}$ cations which have contributed to acid related stresses on crop production (Okalebo et al., 2009). Acid 
infertility factors limit crop growth and yield as well as soil productivity in highly weathered soils of humid and sub-humid regions of the world due to deficiency of essential nutrient elements

In India, the acid soils occupy 90 million ha covering 25 per cent of the total geographical area (Sarkar and Sharma, 2005).About 80 percent of Odisha soils are acidic. Low water holding capacity, high bulk density, and soil crusting along with chemical constraints like low $\mathrm{pH}$, low CEC, low base saturation (16 to67 per-cent), high $\mathrm{Al}, \mathrm{Fe}$ and $\mathrm{Mn}$ saturation, and high $\mathrm{P}$ fixing capacity (80 to 91 per-cent) are major reasons for low crop productivity in such soils (Misra et al., 1989). Acid soils are generally deficient in $\mathrm{Ca}, \mathrm{Mg}, \mathrm{P}, \mathrm{Mo}, \mathrm{B}$, and $\mathrm{Si}$. The availability of $\mathrm{Fe}, \mathrm{Mn}, \mathrm{Cu}$ and $\mathrm{Zn}$ is high, sometimes reaching toxic levels.

These problems can be managed by inorganic and organic ameliorants. Lime application (inorganic) elevates $\mathrm{pH}$, base saturation, and cation exchange capacity and reduces $\mathrm{Al}, \mathrm{Fe}$, and $\mathrm{Mn}$ availability, acidity and $\mathrm{P}$ fixation (Misra et al., 1989; Mishra and Pattanayak, 2002; Sethi, 2015). Organic ameliorants (FYM/compost) reduce exchangeable $\mathrm{Al}$ in soil through precipitation with hydroxyl ions (Sethi, 2015). The organic acids released from organic ameliorants complex with $\mathrm{Al}$ and $\mathrm{Fe}$, reducing their availability and harmful effects. Combined use of organic and inorganic ameliorants simultaneously controls soil acidity, reduces Aland Fe toxicity, and increases nutrient availability (Misra and Das, 2000) leading to better crop growing conditions in these soils. So a pot culture and an incubation study will conduct by using industrial by product and organic residues, which are potential lime sources. Hence, the purpose of the present investigation is to evaluate the "Influence of Integrated nutrient management practices on biomass yield and growth of maize crop in acid soil”.

\section{Materials and Methods}

Soil was collected from Central Horticultural Research Station, OUAT. Then the samples were processed by removing grasses, stones and other waste materials. In each pots $5 \mathrm{~kg}$ of collected soil were filled up. Before sowing calculated amount of calcium silicate, fertilizers and VC mixed properly in experimental soil. Then 3 seeds were sown per pot. The treatments were given to Control $\left(\mathrm{T}_{1}\right)$, Soil test based recommended dose (STD) $\left(\mathrm{T}_{2}\right)$, Vermicompost $\left(\mathrm{T}_{3}\right)$, Lime $\left(\mathrm{T}_{4}\right)$, Lime + vermicompost $\left(\mathrm{T}_{5}\right), \mathrm{STD}+\mathrm{VC} @ 2.5 \mathrm{t}$ $\mathrm{ha}^{-1}\left(\mathrm{~T}_{6}\right), \mathrm{STD}+$ Lime $\left(\mathrm{T}_{7}\right), \mathrm{STD}+\mathrm{VC} @ 2.5$ $\mathrm{t} \mathrm{ha}^{-1}+$ Lime $\left(\mathrm{T}_{8}\right)$.

\section{Collection and processing of plant samples}

At the time of harvesting stage all three plants from each treatment were selected randomly. The roots from different treatments were collected at the time of harvest of the crop by moisturing the rhizosphere, uprooting the plants without disturbing the roots with the help of spade. The entire root and adhered soils were loosen in a bucket of water, saving the roots. Then washed thoroughly and dried.

The mass (weight) and volume was estimated by water displacement method and the density was calculated. The plant parts like stem and roots were kept in separate envelops, washed, labeled properly and dried in hot air oven till a constant weight was recorded. Each sample was grinded separately and was used for analysis of different elements. photosynthetic activity was measured by SPAD cholorophyll meter.

$\left(\begin{array}{l}\text { Relative Agronomic Efficiency (RAE) }= \\ \text { Total Biomass production in treatment }- \\ \text { Total Biomass production in Absolute Control } \\ \text { Totlal Biomass production in STD - } \\ \text { Total Biomass production in Absolute Control }\end{array}\right)$ 


\section{Results and Discussion}

In order to study the "' Influence of Integrated nutrient management practices on biomass yield and growth of maize crop in acid soil" The pot experiment was conducted in an acid sandy loam soil with Maize as the test crop (Hybrid). The experiment was conducted by applying inorganic and organic fertilizer and the soil was ameliorated with a liming materials (Calcium-silicate @ 0.2LR) added with soil test based dose with or without Vermicompost (VC) @ 2.5 t/ha.

Influence of INM practice on growth parameters during crop growth period

\section{Chlorophyll content}

The photosynthetic activity (chlorophyll content) of maize crop under the influence of INM practices had been presented in table 1 .

The photosynthetic activity was measured by SPAD cholorophyll meter. The values recorded at five growth stages starting from $15^{\text {th }}$ DAS till $75^{\text {th }}$ DAS. Rate of increasing of SPAD value was higher in treatment $T_{8}$ as compared to other treatment at $15^{\text {th }}$ DAS and $75^{\text {th }}$ DAS SPAD value was 50 and 77.2 respectively. The rate of increasing is significantly high in limed treatments in comparison to unlimed treatments.

The treatment composed up by only STD, vermicompost and inorganic fertilizer SPAD value was low in comparison to limed treatments. Highest SPAD value (77.2) was observed in $75^{\text {th }}$ DAS of $T_{8}$.

\section{Plant height $(\mathrm{cm})$ and growth rate $(\mathrm{cm} / \mathrm{day})$}

The maize crop heights recorded at different growth stages have been presented in table 2 . The height of the crop continued to grow at differential rates under different treatments. Rate of increasing of plant height was higher in treatment $\mathrm{T}_{8}$ as compared to other treatment at $15^{\text {th }}$ DAS and $75^{\text {th }}$ DAS was 27 $\mathrm{cm}$ and 71.3 respectively. The rate of increasing plant height is significantly high in limed treatments in comparison to unlimed treatments. The treatment composed up by only STD, vermicompost and inorganic fertilizer plant height was low in comparison to limed treatments. Highest plant height (71.3) was observed in $75^{\text {th }}$ DAS of $T_{8}$.

The growth rate of the crop differed from treatment to treatment and from day to day. Growth rate of the crop was 1.02 cmday $^{-1}$ at $15^{\text {th }}$ DAS in absolute control treatment which increased to $1.22 \mathrm{~cm} \mathrm{day}^{-1}$ with STD, still higher with liming materials when used either alone or more with VC, STD + Lime and STD + VC @ 2.5 t ha + Ca-Silicate @ 0.2 LR ranging $1.34 \mathrm{cmday}^{-1}, 1.53 \mathrm{cmday}^{-1}, 1.59$ cmday $^{-1}$ and 1.73 cmday $^{-1}$ (Table 3) respectively at $15^{\text {th }}$ DAS.

The growth rate increased irrespective of the treatments up to $75^{\text {th }}$ DAS except in control. All along the growing period integrated use of inputs had recorded positive influences.

\section{Influence of INM practice on root characteristics}

At harvest, the root weight, volume, and calculated density have been presented in table 4 .

\section{Root volume}

The volume of roots under absolute control treatments ranged was $25 \mathrm{cc}$ is lowest and highest volume of roots was observed in STD + CS @ $0.2 \mathrm{LR}+\mathrm{VC}$ was $58 \mathrm{cc}$. There was significant influence of application of liming materials and their combined use with VC, STD and CS on root volume. Highest root volume was observed in treatment $\mathrm{T}_{8}$ (Table 4). 
Table.1 Influence of INM practice on chlorophyll content

\begin{tabular}{|c|c|c|c|c|c|c|}
\hline \multirow{2}{*}{\multicolumn{2}{|c|}{ Treatments }} & \multicolumn{5}{|c|}{ Days After Sowing } \\
\hline & & 15 & 30 & 45 & 60 & 75 \\
\hline $\mathrm{T} 1$ & Absolute control & 28.5 & 29 & 33 & 37.4 & 40.7 \\
\hline $\mathrm{T} 2$ & Soil test based recommended dose (STD) & 44.5 & 53.2 & 55 & 63.2 & 65.5 \\
\hline T3 & Vermiculite@ $2.5 \mathrm{tha}^{-1}$ & 46.2 & 48.7 & 57.5 & 64 & 66.3 \\
\hline $\mathrm{T} 4$ & Ca-Silicate@0.2 LR & 46.8 & 50 & 57.9 & 64.7 & 67.4 \\
\hline $\mathrm{T} 5$ & VC @ 2.5t ha ${ }^{-1}+$ Ca-Silicate @ 0.2 LR & 48 & 51.5 & 59.3 & 66.8 & 70 \\
\hline T6 & $\mathrm{STD}+\mathrm{VC} @ 2.5 \mathrm{tha}^{-1}$ & 47 & 50.3 & 58 & 65.7 & 69.6 \\
\hline $\mathrm{T} 7$ & STD + Lime & 48.2 & 52 & 60.1 & 67 & 71.5 \\
\hline $\mathrm{T} 8$ & STD + VC @ 2.5 tha ${ }^{-1}+$ Ca-Silicate @ 0.2 LR & 50 & 56.5 & 64.3 & 71 & 77.2 \\
\hline
\end{tabular}

Table.2 Influence of INM treatment on plant height $(\mathrm{cm})$

\begin{tabular}{|c|c|c|c|c|c|c|}
\hline \multirow{2}{*}{\multicolumn{2}{|c|}{ Treatments }} & \multicolumn{5}{|c|}{ Days After Sowing } \\
\hline & & 15 & 30 & 45 & 60 & 75 \\
\hline $\mathrm{T} 1$ & Absolute control & 15.7 & 26 & 29.1 & 32.4 & 34.7 \\
\hline $\mathrm{T} 2$ & Soil test based recommended dose (STD) & 18.2 & 33.5 & 38 & 43.2 & 47 \\
\hline T3 & Vermiculite@2.5 tha ${ }^{-1}$ & 20.1 & 35 & 39.5 & 44.8 & 49.8 \\
\hline $\mathrm{T} 4$ & Ca-Silicate@0.2 LR & 21.2 & 35.9 & 40.3 & 46.3 & 55 \\
\hline $\mathrm{T} 5$ & VC@ $@ .5 \mathrm{t} \mathrm{ha}^{-1}+$ Ca-Silicate @ 0.2 LR & 23 & 37.3 & 43.6 & 47 & 58.5 \\
\hline T6 & STD+VC@ $2.5 \mathrm{t} \mathrm{ha}^{-1}$ & 22.4 & 36.7 & 42 & 46.3 & 57 \\
\hline $\mathrm{T} 7$ & STD + Lime & 23.5 & 38 & 44.9 & 52.6 & 63.8 \\
\hline $\mathrm{T} 8$ & STD+VC@2.5 tha ${ }^{-1}+$ Ca-Silicate @ 0.2 LR & 27 & 42 & 51.7 & 59.5 & 71.3 \\
\hline
\end{tabular}

Table.3 Influence of INM treatment on plant growth rate $(\mathrm{cm} /$ day)

\begin{tabular}{|c|c|c|c|c|c|c|}
\hline \multirow{2}{*}{\multicolumn{2}{|c|}{ Treatments }} & \multicolumn{5}{|c|}{ Days After Sowing } \\
\hline & & 15 & 30 & 45 & 60 & 75 \\
\hline T1 & Absolute control & 1.02 & 1.16 & 0.96 & 0.81 & 0.71 \\
\hline $\mathrm{T} 2$ & Soil test based recommended dose (STD) & 1.22 & 1.46 & 1.28 & 1.07 & 1.01 \\
\hline $\mathrm{T} 3$ & Vermiculite@2.5 tha ${ }^{-1}$ & 1.31 & 1.49 & 1.34 & 1.11 & 1.04 \\
\hline $\mathrm{T} 4$ & Ca-Silicate@0.2 LR & 1.34 & 1.52 & 1.36 & 1.17 & 1.08 \\
\hline T5 & VC@ $@ 2.5 \mathrm{tha}^{-1}+\mathrm{Ca}$-Silicate @ $0.2 \mathrm{LR}$ & 1.53 & 1.61 & 1.44 & 1.36 & 1.24 \\
\hline T6 & STD+VC@ $2.5 \mathrm{t} \mathrm{ha}^{-1}$ & 1.42 & 1.5 & 1.41 & 1.33 & 1.18 \\
\hline $\mathrm{T} 7$ & STD + Lime & 1.59 & 1.68 & 1.51 & 1.44 & 1.35 \\
\hline $\mathrm{T} 8$ & STD+VC@2.5 tha ${ }^{-1}+$ Ca-Silicate @ 0.2 LR & 1.73 & 1.81 & 1.71 & 1.6 & 1.52 \\
\hline
\end{tabular}


Table.4 Influence of INM practice on root characteristics

\begin{tabular}{|c|c|c|c|}
\hline & Treatments & Root volume (cm3) & Root density (g/cm3) \\
\hline T1 & Absolute control & 25 & 0.18 \\
\hline T2 & Soil test based recommended dose (STD) & 34.1 & 0.16 \\
\hline T3 & Vermiculite @ 2.5 t ha $^{-1}$ & 37.4 & 0.17 \\
\hline 3z & Ca-Silicate @ 0.2 LR & 38 & 0.17 \\
\hline T5 & VC @ 2.5t ha + Ca-Silicate @ 0.2 LR & 43 & 0.18 \\
\hline T6 & STD + VC @ 2.5 tha $^{-1}$ & 46.8 & 0.17 \\
\hline T7 & STD + Lime $^{-1}+$ Ca-Silicate @ 0.2 LR & 51.1 & 0.18 \\
\hline T8 & STD + VC @ 2.5 t ha & 58 & 0.19 \\
\hline
\end{tabular}

Table.5 Biomass yield $\left(\mathrm{g} \mathrm{pot}^{-1}\right)$ and relative agronomic efficiency (\%)

\begin{tabular}{|c|c|c|c|c|c|c|}
\hline & Treatments & Root & Shoot & $\mathrm{R}: \mathrm{S}$ & $\begin{array}{l}\text { Total biomass } \\
\quad\left(\mathrm{g} \mathrm{pot}^{-1}\right)\end{array}$ & $\begin{array}{c}\text { Relative Agronomic } \\
\text { Efficiency }(\%)\end{array}$ \\
\hline $\mathrm{T} 1$ & Absolute control & 4.6 & 8.1 & 0.57 & 12.7 & \\
\hline $\mathrm{T} 2$ & $\begin{array}{l}\text { Soil test based recommended dose } \\
\text { (STD) }\end{array}$ & 5.7 & 12.93 & 0.44 & 18.63 & 100 \\
\hline $\mathrm{T} 3$ & Vermiculite@2.5 tha ${ }^{-1}$ & 6.1 & 13.5 & 0.45 & 19.6 & 116.4 \\
\hline $\mathrm{T} 4$ & Ca-Silicate @ 0.2 LR & 6.6 & 14.9 & 0.44 & 21.5 & 148.4 \\
\hline $\mathrm{T} 5$ & VC @ 2.5tha ${ }^{-1}+\mathrm{Ca}-$ Silicate @ $0.2 \mathrm{LR}$ & 7.3 & 16.5 & 0.44 & 23.8 & 187.2 \\
\hline T6 & $\mathrm{STD}+\mathrm{VC} @ 2.5 \mathrm{tha}^{-1}$ & 6.4 & 15.6 & 0.41 & 22 & 156.8 \\
\hline $\mathrm{T} 7$ & STD + Lime & 8.4 & 18.7 & 0.45 & 27.1 & 242.8 \\
\hline $\mathrm{T} 8$ & $\begin{array}{c}\text { STD + VC @ } 2.5 \text { tha }^{-1}+\text { Ca-Silicate @ } \\
0.2 \mathrm{LR}\end{array}$ & 10.33 & 25.2 & 0.41 & 35.53 & 385.0 \\
\hline
\end{tabular}

\section{Root density}

As a result of variation in root weight (mass) and volume of maize crop due to the application of liming materials either alone or with FYM, their density varied between 0.16 and $0.19 \mathrm{~g} / \mathrm{cc}$.

Biomass yield $\left(\mathrm{g} \operatorname{pot}^{-1}\right)$ and relative agronomic efficiency $(\%)$

The total biomass production of maize crop significantly Varied between 12.7 and $35.53 \mathrm{~g}$ pot $^{-1}$ under the influence of lime, VC and fertilizers applications. The total biomass production of maize crop observed lower in $\mathrm{T}_{1}$ and higher in $\mathrm{T}_{8}$ (STD + VC @ $2.5 \mathrm{t} \mathrm{ha}^{-1}+$ Ca-Silicate@0.2 LR). Individual input had significant influence on biomass production (Table 5).

Considering the efficiency of CS in biomass production taken as 100 , the performance of other integrated treatments varied between $116.4 \%$ and $385 \%$. The performance of different treatments can be arranged as 
follows: $\mathrm{T} 1<\mathrm{T} 2<\mathrm{T} 4<\mathrm{T} 3<\mathrm{T} 5<\mathrm{T} 6<\mathrm{T} 7<\mathrm{T} 8$. The result showed highest RAE (\%) in the treatment $\mathrm{T}_{8}$.

The "Influence of Integrated nutrient management practices on biomass yield and growth of maize crop in acid soil" was studied with the help of pot experiment in the Department of Soil Science \& Agricultural chemistry, C.A, OUAT, BBSR. The limingmaterials used in experiment was an industrially processed source calcium silicate (CS). The CS was applied @ 0.2 LR for monocot crop maize.

The beneficial function of fertilizers application, its integration with lime sources and further combination with $\mathrm{VC}$ was not only reflected on growth on above ground portion but also on underground portion i.e., root. The increase in root mass and density due to integrated use of lime sources with STD.

Root weight, their volume and density were influenced by soil amelioration measure with lime sources and more positively by combined use of VC. Similar results of positive impact of liming on root grown were also reported by Pattanayak and Mishra, 2002.

The proper inorganic nutrition of crop coupled with acid soil amelioration measures with lime sources and further with organic source FYM, not only produced bigger sized cobs which could accommodate more grains compared to no fertilization and no amelioration measure was indicative of better growing environment for higher production with INM practice. The results corroborate the findings of Pattanayak and Mishra, 2002.

The positive influence of proper crop nutrition, soil amelioration with inorganic (lime) and organic (FYM) ameliorants not only restricted to the growth of the maize plant, root but also the biomass production of maize. Under the system of integrated nutrient management, constraints for production were taken care to provide optimum growing environment for maize crop to produce as per the treatment specificity. Combined application of organic ameliorant (VC) with lime sources influenced biomass production. These results indicate that combined use of inorganic and organic ameliorants is essential for better yield. But the test was conducted under close system (Pot experiment).These results are in agreement with the results reported by Mishra and Pattanayak (2002), Mishra, 2004, Sharma and Sarkar (2005).

\section{References}

AOAC, 1960. Official Methods of Analysis of the Association of Official Agricultural Chemists, pp 12-13.

Eswaran, H., Reich, P., Beinroth, F. 1997. Global distribution of soils with acidity. In: Moniz A.C., Furlani A.M.C., Schaffert R. E., Fageria N.K., Rosolem C.A. and Cantarella H. (eds.). Plant-Soil Interactions at Low $\mathrm{pH}$. Campinas, Brazil, Brasilian Society of Soil Science. Pp. 159-164.

Jackson, M.L., 1973. Soil Chemical Analysis (Edn. 2) Prentice Hall of India Pvt. Ltd., New Delhi. pp. 69-182.

Kovacevic, V., Bertic, B., Grgic, D. 1993. Response of maize, barley, wheat and soybean to liming on acid soils. Rostlinna Vyroba 39(1): 41-52.

Loncaric, Z., Karalic, K., Vukadinovic, V., Bertic, B., Kovacevic, V. 2005. Variation of liming recommendation caused by calculation approach. In: C.J. Li et al., (eds.), Plant nutrition for food security, human health and environmental protection. Tsinghua University Press. Beijing, China. Pp. 1042-1043. 
Mishra, M., and Pattanayak, S.K. 2002. Response of crops to graded doses of lime amended with or without FYM in different crops grown in acid soil. Professor IFFCO chair report, OUAT, Bhubaneswar.

Misra, U. K., Satpathy, S. and Panda, N. 1989. Characterization of some acid soils of Orissa 1- Nature of soil acidity. J. Indian Soc. Soil Sci. 37: 22-28.

Misra, U.K., and Das, N 2002. Phosphorous availability to maize as influenced by organic amendments. J. Indian Soc. Soil Sci. 48: 298-305.

Okalebo, J.R., Othieno, C.O., Nekesa, A.O., Ndungu-Magiroi, K.W., Kifuko Koech, M.N., 2009. Potential for agricultural lime on improved soil health and agricultural production in Kenya. Afr. Crop Sci. Conf. Proc. 9: 339-341.
Rengel, Z., (ed.): 2003. Handbook of Soil Acidity. Marcel Dekker, Inc. New York, Basel.

Sarkar, A.K., and Sharma, P.D. 2005. Managing Acid Soils for Enhancing Productivity. National Resourse Management Division (ICAR), New Delhi. pp.23.

Sethi, D., 2015. P. G. Thesis submitted to Dept. Soil Sc. and Agril. Chem, OUAT. Effect of LD slag as soil ameliorant and its impact on native PSB population in acid Alfisols of Bhubaneswar.

Sumner, M.E., Noble, A.D. 2003. Soil acidification: The world story. In: Rengel. Z, (Eds.). Handbook of Soil Acidity, Marcel Dekker, New York. pp. $1-28$.

\section{How to cite this article:}

Tupaki Lokya, Antaryami Mishra, J. Ravinder, Sugyata Shivhare and Suraj Mali. 2017. Influence of Integrated Nutrient Management Practices on Biomass Yield and Growth of Maize Crop in Acid Soil. Int.J.Curr.Microbiol.App.Sci. 6(9): 1429-1435. doi: https://doi.org/10.20546/ijcmas.2017.609.173 